Deák Dániel

\title{
EGY HUXIT LEHETSÉGES JOGI KÖVETKEZMÉNYEI
}

\author{
ELÖFELTEVÉSEK
}

Már 2016-ban akadt olyan politikai szereplö Magyarországon, aki népszavazást szorgalmazott az Európai Unióból való kilépésröl (a huxitról). Mások ez ellen kezdtek aláirásgyüjtésbe. Ha bekövetkeznék Magyarország kilépése az unióból, akkor az minden bizonnyal egy olyan kormányzat alatt történhet meg, amelynek müködése alapvetöen eltér a nemzetközileg elfogadott demokratikus és jogállami normáktól. Másként ugyanis józan ésszel aligha képzelhetö el, hogy egy olyan külsö kapcsolatoknak kitett és sérülékeny ország számára, mint Magyarország - a 2004-es csatlakozáskor még Magyar Köztársaság - vonzó perspektiva lenne az élet az unión kivül.

\section{Egyre szorosabb unió}

Kevés esély kínálkozik arra, hogy érdemi magyarázathoz jussunk, ha azt kíséreljük meg feltárni, hogy a hatalom gyakorlói milyen előnyök és hátrányok mérlegelése mentén hozhatnak döntést a kiválásról. Annyit tudunk, hogy az egyeduralomra törekvő fél-állampárt a hatalmat a hatalom kedvéért gyakorolja. Valós politikai tartalmak - a társadalmi igazságosságról vallott elképzelések megvalósítására irányuló koncepciók - csak a hatalom akarásának melléktermékeként jelenhetnek meg. Racionálisan múködő közigazgatás - és ezt tápláló kapitalista gazdaság - révén technikai értelemben még akkor is biztosítható a mindennapi élet struktúráinak újratermelése a normalitás keretein belül, ha a közösségi cselekvésnek a politikai tartalmát tekintve üres, egyeduralomra törekvő politika szab irányt. Ennek legjobb példája a náci uralom alatt létrejött kettős állam, ${ }^{1}$ és ilyenné kell válnia annak a Magyarországnak, amely döntést hoz az unióból való távozásról.

\section{https://doi.org/10.47630/KULG.2019.63.5-6.19}

Deák Dániel, egyetemi tanár, Budapesti Corvinus Egyetem, Közgazdaságtudományi Kar, Összehasonlító és Intézményi Gazdaságtan Tanszék. E-mail: ddd@t-online.hu

${ }^{1}$ Lásd: Ernst Fraenkel, The dual state; A contribution to the theory of dictatorship; Translated from the German by E. A. Shils, in collaboration with Edith Lowenstein and Klaus Icnorr; Oxford University Press, New York, 1941, 205-206. o. 
Intézményi berendezkedését tekintve az unió nincs felkészülve arra, hogy egy tagállam kiválását kezelje, bár hosszas tárgyalásokat követően több menetben sikerült egyezséget tető alá hozni a kiváló Egyesült Királysággal (brexit). Az érintett tagállamban ugyanakkor tragikomikus jeleit látjuk annak, hogy mennyire lehetetlennek tủnik a távozás lebonyolítására többségi politikai akaratot és világos forgatókönyvet kialakítani. Kikényszeríthető jogi következmények nélkül ugyan, de formálisan is megerősítést nyert a mai unió történetének kezdeteitől fogva, hogy az európai integráció egyetlen elképzelt perspektívája az egyre nagyobb egység, a tagállami jogok mind teljesebb közelítése egymáshoz (lásd mai formájában az Európai Unióról szóló szerződés 1 . cikkét). ${ }^{2}$

Az európai népek egyre szorosabb uniójának eszméjéhez képest 1983-ban a tagállamok uniójának gondolata is megjelenik az Európai Tanács Stuttgartban keltezett ünnepélyes nyilatkozatában. ${ }^{3}$ Ennek megtétele nem előzmények nélküli. Az Európai Unió Bírósága (EUB) már az integráció hajnalán, első kritikus ítéleteiben (lásd Van Gend en $\operatorname{Loos}^{4}$ vagy Costa $^{5}$ ) kategorikusan kinyilvánította, hogy a közösségi jog szuverén. Ez azt jelenti, hogy a közösségi jog értelmezése és alkalmazása független a tagállami akarattól. Az európai polgároknak nem kell tehát megvárniuk azt, hogy miként ítélnek a tagállami hatóságok, hanem jogaik - mindenekelőtt a határon átnyúló alapvető szabadságok - érvényesítése céljából közvetlenül az uniós jogra hivatkozhatnak.

Az uniós joggyakorlat a kezdetektől fogva úgy alakult, hogy ítéletek a tagállami intézkedések gazdasági hatásainak felmérése alapján születtek meg. Az uniónak nincs mit kezdenie önmagában egy tagállami törvénnyel, például a kiskereskedelmi forgalomba kerülő termékek minimális alkoholtartalmáról szóló német törvényi elöírással (Cassis de Dijon ${ }^{6}$ ) vagy az ilyen termékek eredetigazolást elöíró törvényi rendelkezéseivel (Dassonville ${ }^{7}$ ). Ha a körülmények úgy alakulnak, hogy ezeknek a törvényeknek egyébként tagállami léptékben jogszerü alkalmazása az áruk szabad mozgásának akadályát képezi, akkor azok a közös piacon egész egyszerűen nem alkalmazhatók. 13. 0

2 Az Európai Unióról szóló szerződés, az Európai Unió Hivatalos Lapja, C 115. 2008. május 9.,

3 Stuttgart, 1983. június 19.

4 A Bíróság ítélete, 26/62. sz. ügy, esetjogi azonosító: EU:C:1963:1. Határozatok Tára (EBHT) 1963., 1. o.

5 6/64. sz. ügy, EU:C:1964:66. EBHT 1964., 1141. o.

6 120/78. sz. ügy, EU:C:1979:42. EBHT 1979., 649. o.

7 8/74. sz. ügy, EU:C:1974:82. EBHT 1974., 837. o. 
A tagállami jog nem válik érvénytelenné, azonban a tagállami jogot akkor figyelmen kívül kell hagyni, ha az az alapvető szabadságok érvényesítésének akadálya lenne (Simmenthal ${ }^{8}$ ). Számos terület van, ahol a tagállamok máig nem osztották meg hatáskörüket egymással, ennek ellenére a tagállami jogot ebben az esetben is úgy kell alkalmazni, hogy az összhangban legyen a közösségi joggal (Schumacher ${ }^{9}$ ).

A közös piacon létezik egy ekvivalenciakövetelmény: a tagállami hatóságok gyakorlatait politikai egyezség hiányában is egymáshoz kell igazítani, ha ennek hiánya az alapvető szabadságok gyakorlásának gátja lenne. Ha a jogi elöírások alkalmazása attól függ, hogy egy határon átnyúló helyzetben milyen hatást válthatnak ki, akkor nem tartható be a jogbiztonság és így a jogállamisági követelmény. A fentiekben jelzett jogfejlődésből adódó ellentmondások kiküszöbölésének nincs más útja, mint az, hogy az uniós jogalkalmazásba beépített mintegy antropológiai optimizmusra hagyatkozzunk. Ennek megfelelően a közösségi jogalkalmazás teleologikus, vagyis mindig arra tekintettel történik, hogy az alapvető szabadságok útjában álló akadályok elháríthatók legyenek. A jog önmozgása - jogi perfekcionizmus - nem feltétlenül tetszik a tagállamoknak, ellenállni azonban nem képesek, mert ahhoz politikai konszenzusra lenne szükség, ami azonban rendszerint hiányzik. Az európai integráció alapvetően nem a felső politikai egyeztetésekről szól, hanem arról, hogy a polgárok és vállalkozásaik gyakorolják az uniós jog számukra biztosított szabadságait.

Az uniós döntéshozói gyakorlat jellemző módon azzal szembesül, hogy a belső piac zavartalan müködésének akadályát a kellő harmonizáció hiánya vagy a tagállamok korlátozó jellegủ adminisztratív intézkedései képezik, de nem maga a piac. Ki nem mondott feltételezés szerint ugyanis a piaci folyamatok egyensúly felé tartása szabályszerüség, az attól való eltérés pedig kivétel. Az uniós szabadságok védelmére irányuló állandósult joggyakorlat miatt kialakult egy liberalizációs spirál, az uniós hatóságok ugyanis egyre kevésbé képesek eltérni a már kialakult gyakorlattól. Ha ezt mégis megtennék, akkor önkényesen járnának el, ami az unió jogállami müködést pártoló logikájával nem összeegyeztethető.

A liberalizációs logika látványosan csődöt mondott például akkor, amikor az uniós hatóságoknak szembe kellett nézniük a 2008 őszén kitört globális pénzügyi válság drámai következményeivel. Nyilvánvalóan szükség lenne például egy uniós tranzakciós adóra, amely a pénzügyi hiperaktivitás megakadályozásának hatásos

8 106/77. sz. ügy, EU:C:1978:49. EBHT 1978., 629. o.

9 C-279/93. sz. ügy, EU:C:1995:31. EBHT 1995. I-225. o. 
eszköze lehet, amihez azonban hiányzik az uniós felhatalmazás. Az uniós jog logikájából eredően ugyanis nem kevesebb, hanem több piacra van szükség.

Szintén ki nem mondott feltételezés, hogy a tagállamok egyre szorosabb uniót kívánnak, és bár lehetséges tagállami deviancia, a korlátozó hatású tagállami intézkedéseket az Európai Bizottság monitorozása révén vagy szükség esetén akár az EUB útján le lehet nyesegetni. Az nem bukkan fel a feltevések között, hogy vannak tagállamok, amelyek önös érdekek vezérelte politikai akarata az unió aláásására, nem pedig megerősítésére irányul. Az különösen nem szerepelt a legutóbbi évekig a feltételezések között, hogy a demokratikus és jogállami müködés zavaraival kellene foglalkozni. Bár Görögország és helyenként a mediterrán államok évtizedek alatt megelőlegezhették a gyanút, ám e problémák mégsem kerültek a közfigyelem előterébe.

\section{A brexit és a huxit}

A brexit megrendítő csapás az unióra, amelyben korábban nem kellett - nem lehetett - számolni az egyre több unió irányultságával szembemenő akarattal. Egyszerü kiválással ugyanakkor nem szakíthatók meg és nem számolhatók fel azok a viszonyok, amelyek az EU polgárai számára biztosított jogokból adódnak. Az uniós jog nem nemzetközi jog, az unió nem külföld, az unióban nincsenek kül- és belföldi személyek, a tagállamok között 1993 óta nincs fizikai határellenőrzés, sem külkereskedelem.

Az EUB kifejtette, amikor (a 2/13. sz. véleményében ${ }^{10}$ ) döntést hozott arról, hogy az EU csatlakozhat-e az Emberi Jogok Európai Egyezményéhez, hogy az uniós jogrend a tagállamok között kifejlődött értékközösségen alapul, aminek tiszteletben tartása nem tehető függővé a kiválás aktusától. Az uniós szerződés 2. cikkében rögzített értékek egymással való megosztása csak azért vált lehetővé, mert a tagállamok között kölcsönös bizalom alakult ki. A kiválás nem csupán az uniós jogrendről való mechanikus leválást jelenti, hanem a kölcsönös bizalom megtörését is. Ez akkora kár, amelyet józan ész szerint nem lehet önös tagállami érdekérvényesítésből adódó előnyökkel kompenzálni.

Az uniós szerződés kiválásról szóló 50. cikke rendszeridegen, az értékek kölcsönös megosztása ugyanis nem teszi lehetővé az azoktól való elszakadást. A kiváló tagállam nem válik egyszerüen harmadik állammá, mert a kiválási szerződést nem egy másik állammal kell letárgyalni, hanem egy közösséggel. A brit gazdaság és tár-

10 2014. december 18. EU:C:2014:2454. 
sadalom olyan mélyen egybeépült a többi tagállammal, és az uniós jog olyan mélyen beépült a kiváló tagállam hazai jogába attól függetlenül is, hogy határon átnyúló vagy tisztán belföldi helyzetekről van-e szó. Fokozatos leválás csak sokéves átmenettel képzelhető el, hogy a jelentősebb károk elkerülhetők legyenek.

A brit közvéleményt a nagypénteki egyezmény ${ }^{11}$ sorsa foglalkoztatja elsősorban, amelynek létrejötte nem függetleníthető attól, hogy mindkét érintett tagállam - az Ír Köztársaság és az Egyesült Királyság - az uniós jogrend része. Ezért van az, hogy az unióból való kiszakadás a nagypénteki megállapodást is ellehetetleníti, illetve a nagypénteki megállapodás csak azon az áron menthető meg, hogy az Egyesült Királyság legalább az európai integráció belső magját képező vámunió része marad. A nagypénteki egyezmény nem értelmezhető az uniós jogtól függetlenül és nem tartható fenn az uniós jogrenden kívül. Ha viszont borul a nagypénteki egyezmény, akkor közvetlen és súlyos veszélybe kerül az Egyesült Királyság alkotmányos rendje.

Az Egyesült Királyság természetesen a brexit után is ugyanúgy jogállam marad, mint annak előtte volt. Ez nem érvényes a huxitra, ez utóbbi oka ugyanis egy olyan állam távozása, amely már régóta nem demokratikus és nem jogállam. Ebben az esetben elképzelhető olyan helyzet, amikor az államot foglyul ejtö, szűk és a nyilvánosság számára nem ismert érdekcsoportok több előnyt remélhetnek a kiválástól, mint hátrányt. Számukra az unió soha nem volt érték, a 2. cikkbe foglalt értékközösséget pedig nem tekintik a valóság részének. Ha az uniós értékközösség a huxitot vezérlő állam vezetői számára jelentés nélküli, akkor a csatlakozás vagy a kilépés csupán partikuláris politikai és gazdasági érdekek mérlegelésének kérdése. A huxit melletti döntésnek Magyarország számára nincs jövőhorizontja és általában nincs humán horizontja. Ebből adódóan a huxit a brexittel ellentétben tagállami részről egyszerüen belátható és levezényelhető.

Az amúgy is a látszat által összetartott viszonyok könnyen szétszakíthatók. A huxit a brexit után az unió számára sem jelenthet megrázkódtatást. Sőt az unió megszabadulhat az integrációs politika kerékkötőitöl.

\section{Szép új világ}

A huxit lehetőségének fényében ${ }^{12}$ érdemes közelebbről szemügyre venni az uniós tagsággal járó előnyöket és hátrányokat. Előnyt jelent természetesen az,

${ }^{11}$ Belfast, 1998. április 10.

12 Amit a csatlakozási szerződéssel (Athén, 2003. április 16. Magyarországon kihirdette a 2004. évi XXX. törvény. HL L 236. 2003.9.23. 17. o.) Magyarország letárgyalt az unióval, kiváláskor tartal- 
hogy Magyarország nettó haszonélvezője az uniós tagságnak, vagyis különböző csatornákon többet kap vissza a támogatásban, mint amennyit be kell fizetnie. Mondhatni, ez az ára annak, hogy az ország megnyitotta piacait a tagállamok előtt, szélesre tárva a kaput a fejlettebb tagállamok dömpingáron értékesített termékei és szolgáltatásai elött is.

A dömping elleni védekezés egyik eszköze a szabályozóverseny, vagyis alacsony mértékü adók alkalmazása, áramvonalasított közigazgatási szabályozás, ami például a környezetvédelmi vagy müemlékvédelmi szabályozás fellazításában mutatkozik meg, nem is említve az elszegényített munkajogot. A kormányzat szisztematikusan leértékeli a magyar munkaerőt és a nemzeti fizetőeszközt, hátrasorolja a humán infrastruktúra fejlesztését. Kiemelkedő a szociális dömping szerepe is, vagyis a szakképzett magyar munkaerő elvándorlásának türése vagy egyenesen ösztönzése. Ezeknek az eszközöknek az alkalmazására az unión kívül is szükség lesz, hiszen Magyarország a tőke és technológia nettó importőre, és belátható időn belül az is marad.

Az ország biológiai ereje kimerülőben van, az életminőség csökkenése pedig megállíthatatlannak látszik. Az erőforrásokat nélkülöző és súlyosan megkülönböztető szociálpolitika nem képes a kedvezőtlen tendenciákat feltartóztatni. E körülményektől nem függetlenül a közbizalom és a közintézmények becsülete a zéró érték felé tendál.

Az unióból való kiválás felszámolja ugyan az illiberális magyar állam túlhatalmának máig legjelentősebb korlátját, nemzetközi kötelékek azonban még maradnak, amelyek a magyar kormányzatot bizonyos illemszabályok betartására késztetik. A NATO-nak Magyarország az autoritárius politikai berendezkedés ellenére is lehet hasznos, bár jelentéktelen tagja. A protekcionista gazdaságpolitika jelentős akadálya a tagság a Világkereskedelmi Szervezetben. ${ }^{13}$ A jelenleg 164 államot, közöttük az Orosz Föderációt és a Kínai Népköztársaságot felölelő WTO széles körben írja elő a világkereskedelem liberalizálását, amit az autoritárius államok különösen gyakran bírálnak, de kikezdeni nem tudnak, legfeljebb a liberalizációs elöírásokat úgy-ahogy megkerülni.

Az uniós áru- és szolgáltatási szabadság megszünik ugyan, de a WTO megfelelő korlátai (a vám- és kereskedelempolitikai intézkedések liberalizálása, stb.) továbbra

milag annak a tükörképét kapja, amennyiben az egyezménnyel elért vívmányok visszavonásra kerülnek. Nem veszünk figyelembe a kiváláshoz esetleg kapcsolódó átmeneti szerződést.

${ }^{13}$ NATO-tagság: 1999. március 12-étől. WTO-tagság: 1995. január 1-jétől. Ezt megelőzően GATT-tagság: 1973. szeptember 9-től. 
is érvényben maradnak. Kétségtelenül meg lehet szabadulni például a hozzáadottérték-adó és a jövedéki adók harmonizációs bilincsétől. Magyarország olyan magas hozzáadottértékadó-kulcsokat alkalmazhat általában, vagy olyan alacsony jövedéki adókat vethet ki dohánytermékekre vagy pálinkára, amilyet csak akar, de a WTOelőírások következtében a belső adóztatás továbbra sem vezethet önkényes megkülönböztetéshez vagy protekcionizmushoz.

A Magyarországon letelepedett vállalkozások a huxitot követően nem nyithatnak majd szabadon fióktelepet egy uniós tagállamban. Magyarország továbbra sem vezethet be korlátozásokat a pénz- és tökeforgalomban, mert ennek a WTO- és az IMF-tagság az akadálya. A magyar székhelyü pénzügyi vállalkozások azonban elveszítik úgynevezett európai útlevelüket, ami annyit jelent, hogy a bankot vagy más pénzügyi vállalkozást egy-egy uniós tagállamban újra kell alapítani.

Az állami támogatás a liberalizációs világkereskedelmi előírások miatt továbbra is tilos, de a versenypolitikai mozgástér jelentősen megnő. Így például nemzeti hatáskörbe kerül a gazdasági erőfölény vagy a kartellek megítélése. Fel lehet éleszteni a csatlakozással megszüntetett magyar „offshore” adózási rendszert.

Az energiaellátás, a közösségi közlekedés és a telekommunikáció szervezésében megnő a magyar kormány mozgási szabadsága. Adminisztratív úton korlátozni lehet majd az internethasználatot. A transzeurópai hálózatok várhatóan nem fognak leépülni, de fejlesztésük sem várható. A magyar statisztikai adatszolgáltatás igazodási kényszere megszünik. Az uniós fogyasztóvédelem leépülése azzal jár, hogy a magyarországi piacokon jelentősen nő majd a fogyasztó kiszolgáltatottsága.

A regionális fejlesztés a magyar kormány szabad belátásának függvényévé válik, és határon átnyúló romaprogramok sem fogják terhelni a magyar állami költségvetést. A határon átnyúló igazságügyi együttmüködés az uniós jogsegélyszolgálatokkal együtt leépül, ideértve a menekültek unión belüli fogadásáról szóló dublini rendelet intézményeit is. Ezek után a menekültekkel szembeni bánásmódban már csak a nemzetközi jog fogja korlátozni a magyar kormányt.

A munkavállalás és letelepedés az unión belül nem korlátlan, de nincs kitéve engedélyezési eljárásnak, pontosabban a fogadó állam hatóságai nem mérlegelhetnek. A szabad mozgás lehetősége a magyar állampolgárok számára természetesen azonnal megszűnik. A diplomák automatikus és többoldalú elismerése sem lesz lehetséges. Uniós társadalombiztosítási kártyánkat elveszítjük, a nyugdíj megállapítása során elillan a szolgálati idők egybeszámítása.

Erasmus-hallgatók már nem lesznek Magyarországon, de vízumkönnyítéseket nem lehetetlen letárgyalni. Jó esély van például arra, hogy ha Ausztriába utazunk, 
nem kell majd vízum. Útlevél persze igen, és határellenőrzés is lesz. Magyar állampolgárok nem kapnak majd diplomáciai védelmet olyan országban, ahol Magyarországnak nincs, de valamely tagállamnak van diplomáciai képviselete (például Latin-Amerikában). A vasfüggöny újbóli felállítása nem várható, mivel a magyar kormánynak kényelmes, ha az izgágák rövidebb vagy hosszabb időre távoznak az országból, hazautalásaik pedig gazdagíthatják majd a magyar állami költségvetést.

Utószó

A huxit a Facebookon már realitás. Nem ezért, de nem haszontalan a huxit gondolatkísérletének végiggondolása annak ellenére sem, hogy a fent leírtak bekövetkezése remélhetőleg rémálom csupán. A politikai önkényt szolgáló ideológia mindenesetre hecckampányok révén terjeszthető, amelyekben továbbra is lehetséges az országot elözönlő migránsokat vizionálni vagy képzelt figurát nemzetközi összeesküvések titkos irányítójának megtenni.

A funkcionális racionalitás anyagi alapjait megteremtő kapitalista gazdaság és a politikai önkény házasságából született meg a náci rendszer, és a körülmények ilyen együttállására van szükség ahhoz is, hogy Magyarország ne a Népszövetséget hagyja el, mint tette azt Hitler Harmadik Birodalma, ${ }^{14}$ hanem az Európai Uniót. Az agresszív nacionalizmus térhódítása történetileg minden bizonnyal átmenet, amely csak addig maradhat fenn, amíg a kapitalista gazdaság és a polgári társadalom az egymásra halmozódó gazdasági és politikai válságokból kikeveredik. A behatárolt jövő mégsem jelenthet vigaszt a kortársak számára, akik a huxit miatt egy rossz forgatókönyv megvalósulását és annak évtizedekre kiható súlyosan hátrányos következményeit lesznek kénytelenek elszenvedni.

14 1933. október 14-én. 